\title{
Acute brainstem haemorrhage as a presenting feature of high-grade glioma
}

\author{
Yasmin Aghajan, ${ }^{1}$ Michael L Levy, ${ }^{2}$ Jun Qin Mo, ${ }^{3}$ John Ross Crawford ${ }^{4}$
}

${ }^{1}$ University of California San Diego, School of Medicine, San Diego, California, USA ${ }^{2}$ Department of Neurosurgery, University of California San Diego, San Diego, California, USA

${ }^{3}$ Department of Pathology, University of California San Diego, San Diego, California, USA

${ }^{4}$ Department of Neurosciences and Pediatrics, University of California San Diego, San Diego, California, USA

\section{Correspondence to} Dr John Ross Crawford, jrcrawford@ucsd.edu

Accepted 9 September 2016
CrossMark

To cite: Aghajan $Y$, Levy ML, Mo JQ, et al. BMJ Case Rep Published online: [please include Day Month Year] doi:10.1136/bcr-2016217370

\section{DESCRIPTION}

A 7-year-old previously healthy girl presented with 1-day history of headache and unsteady gait. Neurological examination revealed intranuclear ophthalmoplegia, vertical nystagmus and ataxic gait. CT scan showed hyperdense haemorrhagic lesion in the fourth ventricle (figure 1) and MRI further demonstrated a large focus of haemorrhage in the posterior pons and surrounding oedema with two small foci of enhancement along the anterior margin of the mass (figure 2). Craniotomy was performed for evacuation of the haemorrhage and

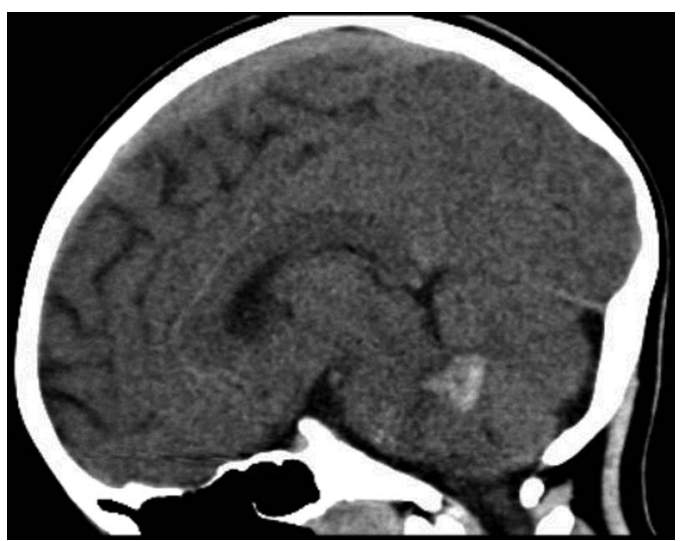

Figure 1 Sagittal CT image demonstrating hyperdense haemorrhagic lesion in the fourth ventricle.

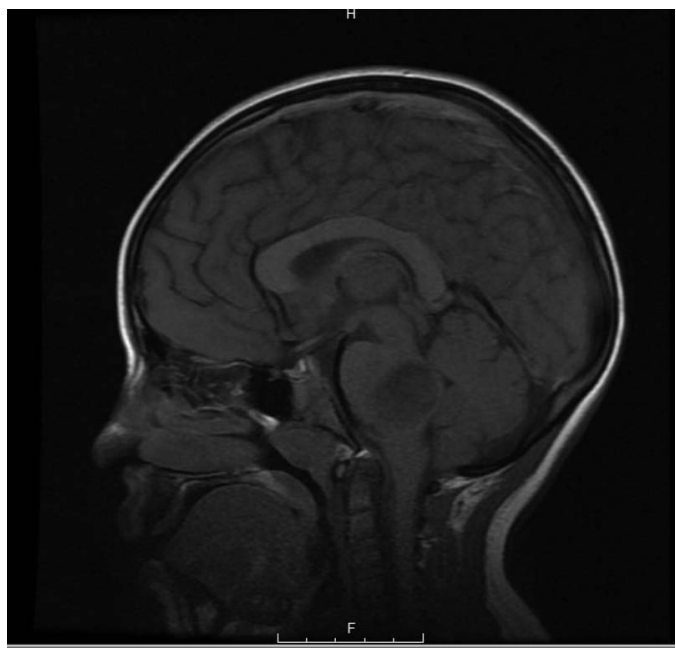

Figure 2 Sagittal T1 weighted image with contrast reveals large hypointense focus of haemorrhage in the posterior pons.

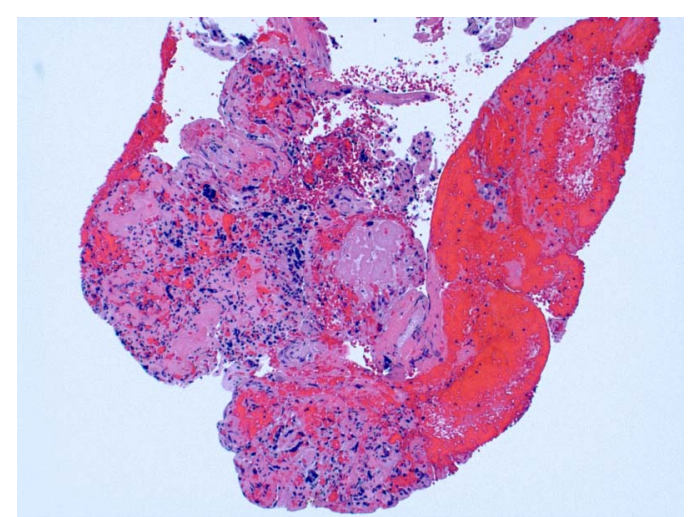

Figure 3 H\&E stain reveals hypercellular glial tumour with pleomorphic nuclei and haemorrhage consistent with a high-grade glioma $(\times 40)$.

biopsies were taken from the area. Neuropathology demonstrated a hypercellular glial tumour with pleomorphic nuclei and haemorrhage consistent with a high-grade glioma (figure 3). Molecular sequencing of the tumour showed mutations in p53, PDGFRa, PI3K, ASXL1 and H3F3A. The patient died 5 months after diagnosis due to disease progression.

The patient's acute presentation of brainstem findings in conjunction with a haemorrhagic brainstem lesion is more commonly seen with aetiology of vascular origin, making this a unique presentation of a high-grade brainstem tumour. The differential diagnosis of brainstem lesions in children includes neoplastic, vascular, infectious and postinfectious causes ${ }^{1}{ }^{2}$ This case highlights that it is important to include high-grade glioma in the differential of acute brainstem haemorrhage and the essential role of biopsy in establishing the diagnosis.

\section{Learning points}

- Gliomas may be indistinguishable from ruptured cavernomas on $\mathrm{CT}$ imaging and should be considered in the differential diagnosis of acute brainstem haemorrhage.

- Brainstem biopsy may be warranted in selected cases of acute brainstem haemorrhage to establish a diagnosis by an experienced neurosurgeon. 
Twitter Follow Yasmin Aghajan at @yaghajan

Competing interests None declared.

Patient consent Obtained.

Provenance and peer review Not commissioned; externally peer reviewed.

\section{REFERENCES}

1 Dellaretti M, Touzet G, Reyns N, et al. Correlation among magnetic resonance imaging findings, prognostic factors for survival, and histological diagnosis of intrinsic brainstem lesions in children. J Neurosurg Pediatr 2011;8:539-43.

2 Quattrocchi C, Errante Y, Rossi Espagnet MC, et al. Magnetic resonance imaging differential diagnosis of brainstem lesions in children. World I Radiol 2016;8:1.

Copyright 2016 BMJ Publishing Group. All rights reserved. For permission to reuse any of this content visit http://group.bmj.com/group/rights-licensing/permissions.

BMJ Case Report Fellows may re-use this article for personal use and teaching without any further permission.

Become a Fellow of BMJ Case Reports today and you can:

- Submit as many cases as you like

- Enjoy fast sympathetic peer review and rapid publication of accepted articles

- Access all the published articles

- Re-use any of the published material for personal use and teaching without further permission

For information on Institutional Fellowships contact consortiasales@bmjgroup.com

Visit casereports.bmj.com for more articles like this and to become a Fellow 